\title{
Comparison of Cultivation Team of Core Values Between Chinese and American Soldiers
}

\author{
Fang Hua, Du Keke, Liu Wenjuan, Yan Hongxin, Gou Yahong, Tian Yanhui \\ College of Information and Communication, National University of Defense Technology
}

\begin{abstract} of the cultivation personnel.

\section{CULTIVATION TEAM OF THE MILITARY CORE VALUES OF CONTEMPORARY REVOLUTIONARY SOLDIERS}

Our military's core values cultivation team and political work team are highly coincident and unified. In more than ninety years of army building practice, our army has reinvented itself on the basis of drawing on the political work system of the former Soviet Red Army, and has formed its own unique political work system. It has a team of officers and soldiers dedicated to the cultivation of the core values of contemporary revolutionary soldiers. Political cadres at all levels, military chiefs and other military officers, political theory instructors and ideological backbones of colleges and universities form a coherent team system from top to bottom, from left to right, and from top to bottom.
\end{abstract}

The cultivation team is the specific organizer, content transmitter, and practice model of the core revolutionary values cultivating project of contemporary revolutionary soldiers. It plays a leading and decisive role in the cultivating process. The study found what the two military cultivation teams have in common: they both have a more comprehensive, complete, and self-adapted military core value cultivation institution system with their own characteristics. The difference is the strength of the cultivation organization, and the quality requirements

Keywords: military core values; China and the United States; cultivation team

\subsection{Political cadres}

Political cadres are the backbone in the cultivation of military core values. Unit political chiefs, political organ cadres, and grassroots political officers are a set of system designs for our military's political work, which embodies the party's principle of leading political work. They are leaders and organizers of political work at all levels, including the cultivation of the military core values of contemporary revolutionary soldiers.

\subsection{Political theory teachers}

Political theory teachers are the powerful force in the cultivation of military core values. Military academies play a leading role in the cultivation of military core values. It is the responsibility of colleges and universities to transform their own scientific research advantages into military combat effectiveness and use research results to provide intellectual support for military cultivation projects. The main body responsible for the cultivation and research tasks of contemporary revolutionary soldiers' core values is the majority of political theory instructors. They are both the cultivation subjects and the believers and model practitioners of the soldiers' core values. Not only do they take on the task of educating people, but also continue to study the theory of effective transformation of values, and constantly summarize and improve the cultivation ability.

\subsection{Military chief officers and other officers}

Military chiefs and other officers are important auxiliary forces in the cultivation of military core values. In the army, they are administrative leaders and members of the team, and they have important responsibilities in the cultivation work.

The military chief officers bear the leadership responsibility for the work of the unit, including the cultivation of the military core values of contemporary revolutionary soldiers. Therefore, the political chief officers of the unit should be actively supported and assisted in the cultivation work. Other officers should adhere to the principle of ideological leadership, consciously model and practice the core values of contemporary revolutionary soldiers, and maintain a good image from the bottom to the top. This is both a duty requirement and a professional development need.

\subsection{Ideological backbones}

The vast majority of ideological backbone is the main strength in the cultivation of military core values. The ideological backbone mainly includes party members, sergeants, squad members, and advanced elements among soldiers at the grassroots level.

The ideological backbones come from the front line. They are the backbone of administration, technology and the grassroots and have unique advantages in cultivation. Their exemplary roles make the values sensible and learnable, 
and more grounded. They have a common life experience with the soldiers, have a clear judgment on the effectiveness and deviation of the cultivation work, and their work is more targeted. During the cultivation process, they interact with each other and help soldiers, which is conducive to the formation of a vivid situation of joint improvement and participation of everyone in the cultivation, reflecting the mass characteristics of the cultivation work.

\section{CULTIVATION TEAM OF THE MILITARY CORE VALUES OF USA SOLDIERS}

Before 1992, the US military mainly relied on military service colleges and padre teams to cultivate the military core values. However, after various military services successively established the core values of military personnel in 1992, the US military established a separate military core value cultivation institution, and gradually paid attention to the construction of the cultivation team. The cultivation personnel of the US military core values are mainly composed of four types: military commanders, sergeants, military school moral instructors and padres.

\subsection{Military commanders}

The US military implements a "one-commander" military leadership system. The military commander is both an implementer, a demonstrator, and an evaluator of the effects of the cultivation of the military core values. In addition to completing the tasks assigned by the leadership, the commander also has the main responsibility for cultivating the core values of officers and soldiers, improving the morale of the troops, and inspiring the creativity of officers and soldiers. Taking the US Air Force as an example, the "Memorandum of Core Values of the Air Force Education and Training Command" clearly states: "The commander will show us relevant content directly through supervision, demonstration and influence." ${ }^{1}$ The military commander is a direct lecturer cultivated by the military's core values. The lectures are generally given by commanders in combination with the tasks of the troops, and with the actual situation of the officers and soldiers. The "Air Force Core Values Training Plan Memorandum" stipulates the education implementation plan: the commander directly communicates to the subordinates the well-prepared and clearly expressed military core values. Military commanders are demonstrators of the military core values. It is clearly stated: "The bottom line of the cultivation requirements for military core values is that all commanders must participate in all levels of cultivation. If possible, the commander should personally lead and implement cultivation in all fields, appropriately combining the expertise of this profession, and playing a role model for leadership is effective in implementation. The fundamental foundation of leadership is the key to winning the honesty and dedication of subordinates." The military commander is also an evaluator of the effectiveness of the military's core values. The Air Force requires the commander to conduct at least two forms of evaluation of the unit's core values, one of which is the original evaluation. When the commander takes office, the goal is to understand the moral ethos in the army, and then formulate and implement a core value education strategy suitable for the unit according to the actual situation. The second is regular evaluation. The assessment is at least annual. The purpose is for the commander to investigate whether the subordinate units have carried out the cultivation of core values and their effectiveness.

\subsection{Professional sergeant}

They are direct managers and educators of soldiers. Most of the sergeants have served for many years and are frontline soldiers. They are similar to the backbone of our army. They are familiar with the life, thoughts and needs of soldiers and play a unique role in the cultivation of soldiers core values. If the commanders in the cultivation process mainly "instruct" according to the regulations, and the padres focus on "influence", then the sergeant is mainly responsible for passing on the value, and soldiers often rely on the sergeant to solve practical problems. This particular identity determines that they are more easily accepted by soldiers. In fact, most of the cultivation work for the US military is done by the sergeant team.

\subsection{Military school moral instructors}

In the US military schools, there are positions like ethics instructors, student advisors, moral instructors, and interpersonal education instructors (navy) held by military officers. They are responsible for implementing courses that teach the military core values. The content of the course includes: the definition and origin of the military core values, the importance of core values to individuals, etc. The content of the class topics is quite detailed, including interpersonal relationships, sexual harassment and level playing field. ${ }^{2}$ On the basis of this, some colleges and universities will also specifically hire ethics professors.

\subsection{Padres}

There are more than 3,000 padres in the US military, which is an important force for the cultivation of the US military core values. Under the Ministry of National Defense, there is the "Armed Force Padres Committee", which is the highest institution in the US military chaplain system. It is generally composed of 6 people, and the post of director is alternately held by the chief padres of the three military 
services of the land, sea and air. The padre's role in cultivating the military core values is very clear in the relevant documents: "Give advice to the commander on mental health and moral issues", "Provide guidance and help for the development strategy and related plans of the soldier's core values." ${ }^{3}$ The padres have two roles in cultivating: tutor and trainer. As a tutor, the padres is the commander's adviser on moral and ethical issues, and uses religious creeds to advise him to make the right decisions. In the eyes of officers and soldiers, they are both the spokesperson of the values of the country and the army, and the incarnation of God. As trainers, more than $90 \%$ of the US military officers and soldiers have religious beliefs, and religious life is everywhere. Padres are required by the military to use religious inspiration to strengthen the professional ethics of soldiers, improve moral standards, and clearly and faithfully perform their duties and missions.

\section{SIMILARITIES AND DIFFERENCES IN THE CULTIVATION OF THE MILITARY CORE VALUES OF CHINSESE AND US SOLDIERS}

\subsection{Similarities}

It is not difficult to find out from the analysis of the core values cultivation team of the US and Chinese soldiers that the armed forces of the two countries have a relatively complete, distinctive and self-adapting cultivation team. The allocation of forces for the construction of the core values of the Chinese and American troops is the result of a combination of factors such as the state, the ideology of the military, and the stage of development. It reflects the adaptive characteristics and the objective necessity of the system. It must be consistent with the national ideology, the military's specific development stage requirements, the military's understanding of the role of political work status, and the military's core values and content construction requirements.

\subsection{Differences}

In comparison, in terms of cultivation the core values of the military, our military has a higher level of coordination than the US military, with more manpower invested, and the qualities of the two military teams have their own characteristics.

\subsubsection{Difference in the strength of the}

\section{cultivation team}

The cultivation team of military core values of Chinese army has a higher staffing level and stronger strength, while the US military's cultivation team has a lower rank and capable personnel. The highest rank of the U.S. military cultivation team is the director of the "Personnel Division" of the Ministry of Defense, and the director is the major general. The institutional level of the padre system is also low, and the director of the General Padres Bureau is also a major general. In more than 90 years of army building practice, Chinese army has created powerful political work necessary for the building and development of the people's army. The "Military Commission" is implemented. The Central Military Commission is the highest decisionmaking body. It has established a set of top-down political work systems. It has an independent team engaged in political work including cultivation. From the perspective of team allocation, the personnel have higher rank and stronger strength, which is a distinctive feature.

\subsubsection{Difference in the quality of the cultivation team}

Based on the above analysis, the differences between the cultivation teams of the two armed forces are mainly reflected in: first, the difference in the overall quality of the team, and second, the difference in the quality of the team of political cadres and the US military padre.

Differences in overall quality: On the one hand, the political quality of our military's cultivation team is stronger than that of the US military. For many years, our army has always paid attention to giving play to the traditional advantages of political work, and strengthened the value orientation of the mainstream army of officers and soldiers through educational guidance and organizational coordination. The cultivation team as a whole has strong party spirit, a strong sense of identity, outstanding performance in major tasks, and can play a role of demonstration and example in the collective. However, due to the deep-rooted tradition of pragmatism, the US military has not cultivated a high spiritual level and moral level in the ranks, especially military commanders and sergeants. In recent years, scandals of officers at various levels in the U.S military have emerged in an endless stream, and sexual harassment, sexual assault, and adultery of officers have become increasingly fierce. Take the Grounded Force as an example. In 2012, a number of senior generals were punished for misconduct, which wiped out the face of highlevel officials. According to a news media, more than half of Army soldiers don't have high praise about the military's professional ethics and belief standards. ${ }^{5} \mathrm{On}$ the other hand, the comprehensive quality of the US military cultivation team is better than that of our military. First, it is reflected in the academic level, and the cultural level of 
the US military officer ranks is generally higher. According to statistics, the proportion of graduate education in US Air Force officer is as high as $51 \%$, and the proportion of masters and doctoral students of other military services reaches $38.4 \%$. Although in recent years our military has adopted various methods to improve the educational level of military officers, there is still a gap compared to the US military. The second is reflected in "one specialty and many abilities". U.S. military vocational education is known for its "thick foundation and quality." Whether it is a military commander, a military school moral instructor, or a military padre, many have more than two bachelor's degrees. Commanders are required to not only engage in military work, but also in ideological education work, and must become "military politicians" and "strategists." Padres who follow the army are often "generalists". Not only are they highly educated, but many are well versed in the beauty of art, literature, and history. In contrast, our military's political cadre team has a relatively simple experience structure, and has a shortcoming in military professionalism and joint combat command capabilities. The investigation revealed that their compound qualities of arms and services and their ability to command joint operations have not been comprehensively trained.

Differences in the quality of political cadres and US military padres: In the cultivation of the military core values of the two armed forces, there is some overlap in the functions of our military political cadres and US military padres, such as the regular ideological work and psychological service during the cultivation process. ${ }^{6}$ There are similarities, but the difference between our army's political cadres and the US army's padres is also obvious. The biggest difference between the two's overall qualities focuses on the practice of political and religious beliefs. As mentioned earlier, the overall quality of the US military padres is generally high, generally graduated from seminary with excellent results. Except for religious affairs, most of them are highly educated and compound talents. In addition to their high level of education, the overall moral standards of the US military padres team are good, and they are highly trusted by officers and men. Our army believes in communism. Marxism-Leninism, Mao Zedong Thought, and the theoretical system of socialism with Chinese characteristics have become the firm political beliefs of our military officers and soldiers. The political work of the military is the lifeline of our military. Political cadres at all levels are direct disseminators of our values, firm practitioners, and advanced demonstrations. In short, our army's belief and practice are unified. This is fundamentally different from the US military's "faith is faith, action is action", which usually shouts "freedom, democracy, human rights", but conduct indiscriminate killings of innocents on battlefields around the world. Scandals, abuses, and wrongful killings of civilian population appear every year, which reflects the conflict and serious departure from the beliefs and actions of the US military. The bravery and tenacity of the Chinese army on the North Korean battlefield are obvious to the whole world. Where does this spirit come from? This is because political cadres penetrate the concept of a just war into the bones of every combatant. At the same time, leading by example on the battlefield of political cadres is the most powerful persuasion education for officers and soldiers.

\section{CONCLUSION}

In conclusion, according to the different national conditions and military conditions, the Chinese and American armed forces have established a military core value cultivation team suitable for their own military characteristics. Our army's political work has become our army's greatest feature. Therefore, in cultivating the core values of soldiers, our army can concentrate its strengths and power, and its staffing structure is larger and strength is stronger. The cultivation system of the military core values in the US army is integrated with the military system, and there is less human and material investment in the cultivation work than our military. As far as the quality of the military's core values is concerned, the overall quality of the US military is stronger than that of our military, but the political quality of our military is better than that of the US military. The padres of the army have a high moral level, but because the US military implements the principle of "separation of politics and religion", it is in a moral dilemma, and political cadres in our army can better integrate their political beliefs into military practice. Therefore, in continuing to deepen the cultivation of the core values of military personnel, we must persist in reform and innovation. However, we should not copy the practices of other countries' military forces at will, but adhere to a prudent attitude and must not blindly follow suit.

\section{REFERENCES}

[1] "Education on Core Values of the US Air Force", PLA Press, 2008, p. 190.

[2] "Education on Core Values of the US Air Force", PLA Press, 2008, p. 122.

[3] Secretary of the Navy. Religious ministry support within the Department of the Navy. File SECNAVINST. 1730.8A, National Archives. Office of the Chief of Naval Operations,"Religious ministries in the Navy,"file OPNAV 1730.1C, National Archives.

[4] Xu Jianyi \&Yuan Jing: "The U.S. Army's Padres System and Its Role", contained in "Theoretical Studies on Political Work in the Army", No. 1, 2001, pages 94-95.

[5] Liu Yangyue. Research on Practical Teaching Reform and Innovation of Ideological and Political Theory Course in the All-media Era[J]. The Science Education Article 
Collects,2019(12c):68-70.

[6] Zhu Wenyan. Exploration on the Practice Teaching of Ideological and Political Theory Course of "Moral and Technical Training combined with Study and Study" Education Mode [J]. Beijing Education,2020(2):50-51. 